\title{
El Estado peruano durante el siglo XX. Aspectos teóricos y periodización
}

Osmar Gonzales

Biblioteca Nacional de Perú

Luego de hacer un breve repaso sobre alguna literatura general relevante acerca del proceso de formación del Estado, el autor se centra en el caso peruano durante el siglo XX, tratando de justificar una periodización distinta a la usualmente utilizada en las ciencias sociales peruanas para, finalmente, llegar a algunas preguntas acerca de si el Estado peruano ha podido constituirse o no en un actor racional.

El propósito de las siguientes páginas es modesto: sólo destacar algunas "pistas" importantes para tratar de comprender el complejo proceso de construcción del Estado en el Perú durante el siglo XX, a partir de dos tensiones básicas:

La primera tensión es la que se expresa entre los intentos por construir un poder central (el Estado como arena de resolución de conflictos) y la persistencia de los privilegios de los poderes privados.

La segunda tensión se manifiesta en la pugna de los sectores sociales excluidos para abrir el sistema y ampliar la base ciudadana del Estado (conquista de derechos) y el esfuerzo de las elites que controlan el aparato estatal para incorporar — sólo segmentadamente- a ciertos sectores sociales al sistema político.

En lo posible, evito caer en dicotomías que pueden reducir el análisis, como la que separa lo nacional-popular de lo nacional-estatal. ${ }^{1}$ Prefiero ubicar mi perspectiva en el entendimiento de que la sociedad y el Estado son partes de una misma relación. En esta línea argumentativa se ubica, por ejemplo, el trabajo de David Nugent ${ }^{2}$ quien, después de hacer una revisión bibliográfica sobre el tema del Estado, señala que las relaciones entre éste y la sociedad hay que entenderlas como compuestas tanto por la cooperación como por el conflicto, y no sólo por la permanente oposición. Una aplicación de este modo de entender las relaciones recíprocas de las clases subalternas y el Estado es la que nos ofrece Viviane Brachet quien,

1 Portantiero, Juan Carlos: "Lo nacional-popular y la alternativa democrática en América Latina", en Henry Pease et. al.: América Latina 80: democracia y movimiento popular, Lima, 1981.

2 Nugent, David: "Building the State, making the nation: the bases and limits of State centralization in modern Peru", en American Anthropologist, Vol. 96, núm. 2, junio, 1994. 
utilizando el concepto de "pacto de dominación", ${ }^{3}$ logra una interesante relectura del proceso político mexicano, cuestiona el análisis hegemónico que consiste en afirmar que el Estado siempre ha poseido la iniciativa en el tema de las reformas a aplicar y revela el papel principalísimo que han cumplido las clases subalternas en la definición de las políticas estatales. En consecuencia, el Estado y la sociedad interactúan permanentemente y ayudan a transformarse y a constituirse; no se les puede entender por separado.

De una manera algo forzada, pero espero que ilustrativa, puedo afirmar que el proceso del Estado peruano en el siglo XX tiene algo de paradójico: ha vuelto al punto donde comenzó, es decir, el del manejo privatizado del poder. Si bien en el largo período que comprende un siglo las clases subalternas conquistaron espacios a manera de oleadas - $\mathrm{O}$ de "incursiones democratizadoras", como prefiere denominar Sinesio López ${ }^{4}$ a las conquistas democráticas de las clases populares-, desde los años ochenta, luego de más de una década de violencia política, crisis económica y ciertos grados de descomposición social, la sociedad peruana se encuentra exhausta y con capacidad de resguardar sólo lo que le resulta urgente e imprescindible, especialmente actividades ligadas a la supervivencia. En ese contexto es relativamente explicable que ciertos derechos civiles y sociales — vulnerados por el régimen autoritario del ingeniero Alberto Fujimori (1990-2000) — no sean considerados por los sectores mayoritarios como "artículos de primera necesidad" y el manejo privatizado del Estado haya tenido carta libre.

\section{El proceso del Estado nacional: aspectos teóricos generales}

Históricamente, la consolidación del Estado nacional es producto de un proceso sumamente largo. Ha sido usual que, teniendo como referentes clásicos a los procesos formativos de los estados nacionales europeo-occidentales, los estudios historiográficos se hayan caracterizado por establecer cortes temporales en los grandes momentos de la historia: Antigüedad, Feudalismo, Época Moderna. La consecuencia de esta estrategia metodo-

3 Brachet, Viviane: El pacto de dominación. Estado, clase y reforma social en México (19101995). México, 1996.

4 López Jiménez, Sinesio: Ciudadanos reales e imaginarios: concepciones, desarrollo y mapas de la ciudadanía en el Perú. Lima, 1997. 
lógica es que dejó rezagada de los análisis la profunda vinculación que existe entre esas etapas en los momentos transicionales.

En este sentido, Perry Anderson ${ }^{5}$ es un renovador en la manera de entender el proceso formativo del Estado en Europa. Su análisis parte del estudio del mundo antiguo para poder iluminar la manera cómo surgió el feudalismo que, a pesar de ser distinta a la época anterior, no significó una ruptura radical y sin herencia.

De igual modo, Anderson analiza la transición ocurrida entre la crisis del feudalismo y la aparición del Estado Absolutista. El mencionado autor parte de la premisa metodológica siguiente: que no hay un tiempo homogéneo en la aparición, desarrollo y crisis del Absolutismo, sino que las variaciones pueden explicarse en función de cada entorno nacional, aun cuando exista un patrón básico que singularice a dicho Estado. ${ }^{6}$

La importancia que asume el estudio del Estado para Anderson consiste en que es en él, en tanto representante por excelencia de lo político, donde se resuelven las contradicciones entre las clases. En otras palabras, no se trata de privilegiar sólo una historia "desde abajo" que se centralice en las luchas de las clases sociales por conquistar el dominio; se hace necesario también el estudio "desde arriba" para tener una imagen completa de los procesos históricos.

En la misma línea argumentativa, Arno Mayer ${ }^{7}$ estudia el proceso contradictorio que dio paso a la sociedad moderna, para lo cual parte de tres premisas. La primera es que las dos guerras mundiales del siglo XX están íntimamente ligadas, constituyendo lo que llama la Guerra de los Treinta Años. La segunda es que la Gran Guerra (1914-1918) fue producto del intento del Antiguo Régimen por mantenerse con vida frente a la sociedad moderna e industrial, capitalista en suma. La tercera, y más importante, es que el Antiguo Régimen "era totalmente preindustrial y preburgués". Con ello, Mayer desea demostrar que el Antiguo Régimen persistió hasta bien entrado el siglo XX, contradiciendo a la mayoría de estudios historiográficos que señalaban que había sido eliminado definitivamente en 1789. El tema es, pues, las modalidades que ocurren en las transiciones de una organización económica, política y social a otra. De lo que se trata es de entender el proceso constitutivo del Estado en momentos de transición de un ordenamiento social a otro.

5 Anderson, Perry: Transiciones de la antigüedad al feudalismo. México, 1982.

6 Anderson, Perry: El Estado absolutista. México, 1980.

7 Mayer, Arno: La persistencia del Antiguo Régimen. Madrid, 1984. 
Michael Mann ${ }^{8}$ señala que son cuatro las actividades principales del Estado: mantener el orden interno, la guerra externa, mantener la infraestructura de comunicaciones y la redistribución económica. Si bien éstas pueden ser emprendidas tanto por la sociedad entera como por grupos de interés, quien más eficazmente las emprende es el personal de un Estado central. Ello permite al Estado comprometer a grupos no sólo distintos sino incluso contrapuestos, pudiendo oponerlos para mantener cierto nivel de autonomía con respecto a ellos. Dicha característica es más visible en lo que Mann llama "Estado transicional", ubicado en medio de "profundas transformaciones económicas de un modo de producción a otro". En esta situación no existe una clase económica dominante, y el Estado tiene la posibilidad de enfrentar a los grupos emergentes contra los tradicionales.

El elemento que define al Estado nación, siempre según Mann, es su naturaleza "institucional, territorial, centralizada". Además, el Estado combina formas de poder - económico, militar e ideológico- presentes en todas las relaciones sociales. No obstante, sólo el Estado está centralizado con respecto a "un territorio delimitado sobre el que tiene el poder autoritario". El Estado se constituye tanto en un lugar central como con un alcance territorial unificado. De aquí deviene el poder autónomo estatal, pues tiene un campo de acción territorial distinto al de las clases. Por otro lado, la centralización territorial permite al Estado la movilización del poder para el desarrollo social.

Con base en estos criterios, Mann polemiza implícitamente con Anderson (en realidad con el marxismo y el funcionalismo los que, dice, tienen visiones reduccionistas) al señalar que el Estado no es simplemente un espacio en el que las luchas de clases y grupos de intereses se expresan. Mann afirma que el Estado ostenta un cierto poder autónomo, por ello lo estudia como un actor personificado en las elites estatales y con voluntad de poder. Es, en alguna medida, un actor racional. Por eso para Mann, si bien el Estado es una arena, es de esa condición de donde surge su poder autónomo dado que responde a la necesidad de que las actividades de la sociedad civil se regulen dentro de un territorio limitado y centralizado.

Respecto al carácter evolutivo del Estado, Mann señala que los Estados-naciones que conocemos ahora no son un producto del capitalismo (ni del feudalismo), sino el resultado "de la manera en que los Estados pre-

8 Mann, Michael: "El poder autónomo del Estado: sus orígenes, mecanismos y resultados", en Michael Mann y Chris Wickham: La autonomía relativa del Estado, Cuadernos de Ciencias Sociales, núm. 59, Costa Rica, 1993. 
existentes dieron fronteras normativas a las expansivas, emergentes, relaciones capitalistas". ${ }^{9}$ La evolución sostenida desde la época medieval hasta la moderna es decisiva para entender las transformaciones modernizadoras y en nuestro tiempo lo es la relación existente entre los estados nacionales y el sistema mundial, especialmente en cuanto a los problemas de la centralización y la territorialización.

Ahora bien, ¿por medio de qué mecanismos es posible lograr la centralidad del Estado? Pueden ser varios, quizás el más antiguo sea el de la guerra. Bruce Porter ${ }^{10}$ analiza las que denomina "las paradojas de la guerra", en el sentido de que el campo de batalla puede significar destrucción y caos, y que sin embargo detrás de esta realidad se pueden hallar el orden y las reglas. La necesidad de proveer y transportar los equipos necesarios a los combatientes implica un grado de centralización, formación de una burocracia acondicionada para responder a las circunstancias y empleo de tecnologías adecuadas. La centralización permite saber quiénes y cuántos pueden ir a la guerra y obliga al Estado y a sus elites a tener un conocimiento de los recursos disponibles dentro de un territorio dado. Es decir, existe una relación estrecha entre destrucción y organización. Es la destrucción la que fuerza a organizar: la guerra también es disciplina.

Otro elemento que coadyuva a la conformación del Estado es el de las estadísticas, las cuales aparecen como una necesidad de aquél para afrontar problemas como la recaudación de impuestos. La Estadística, es decir, la ciencia de Estado, permite a éste conocer a su población: cuántos son, su distribución por edad; cuántos están en edad de trabajar y pueden, por lo tanto, pagar impuestos y su distribución sobre el territorio "nacional". Todos estos elementos constituyen una información que aparece como más perentoria de obtener a medida que el poder personal desaparece para dar paso al ejercicio impersonal del gobierno. Las estadísticas, en suma, son un medio que permite proyectar ciertas políticas estatales. ${ }^{11}$

La alfabetización constituye otro elemento presente en la conformación del Estado. Tomando como referencia las primeras etapas de la alfabetización en Mesopotamia (aunque no se trate de un caso único y aislado, sino seguramente repetible) Mann señala que se dio primero al interior del Estado, en su burocracia, produciendo con ello la codificación y estabilización de dos normas: derechos de la propiedad privada y derechos y debe-

9 Ibidem, pág. 42.

10 Porter, Bruce D.: War and the rise of the State. New York, 1994.

11 Hacking, Ian: La domesticación del azar. Barcelona, 1991. 
res comunitarios. La alfabetización permitió mejorar los sistemas de contabilidad sobre propiedades y adeudos, la escritura centralizó las relaciones (antes demasiado disgregadas) en torno al Estado y coadyuvó a la implantación de sistemas de justicia. ${ }^{12}$

Existen otros elementos que actúan en la formación del poder estatal sobre un territorio delimitado, como el papel ya mencionado que cumple la ley y la extensión de las ideologías. En general se trata de procesos de larga duración

\section{El Estado peruano: un ogro inútil}

En el Perú, haber entendido el proceso histórico de formación del Estado como un continuum ha conducido a privilegiar las permanencias - que efectivamente existieron - y menospreciar las modificaciones, orientando un tipo de lectura que se puede denominar organicista. ${ }^{13}$ En sentido contrario, leer la historia como una sucesión de etapas ha sesgado a una lectura en la que predomina la sucesión de hechos atendiendo sólo a lo contingente sin considerar lo heredado. ${ }^{14}$ Una consecuencia de estas lecturas disímiles es que las polémicas en torno al Estado en el Perú han estado teñidas de una clara carga ideológica. No obstante, existe una idea más o menos aceptada en las ciencias sociales peruanas: considerar al Estado como una institución inútil.

En efecto, tanto liberales como marxistas coinciden en señalar que el Estado peruano siempre ha estado alejado de la sociedad "real". Los pri-

12 Mann, Michael: "El poder autónomo del...”, págs. 20-21. Para la importancia que adquirió la imprenta y lo que llama "capitalismo impreso" en la constitución de comunidades nacionales, ver el libro de Anderson, Benedict: Comunidades imaginarias. Reflexiones sobre el origen y la difusión del nacionalismo, México, 1993. Y sobre el papel de la escritura en las relaciones sociales y sus repercusiones en el plano de las ideas ver las primeras páginas del artículo de Schofield, R.S.: "Los niveles de alfabetización en la Inglaterra preindustrial", en Jack Goody (Compilador): Cultura escrita en sociedades tradicionales, Barcelona, 1996.

13 Según Julio Cotler: Clases, Estado y nación en el Perú, Lima, 1978, por ejemplo, el proceso seguido por el Estado peruano es particular en América Latina por la fuerte presencia de lo que denomina "la herencia colonial". Ésta tiene dos consecuencias. Primero, prefigura el carácter dependiente del Perú respecto del capitalismo hegemónico, y segundo, preserva las "relaciones coloniales" en la explotación de la mayoritaria población indígena. Ambos elementos impidieron una integración plena de la sociedad, generando la marginación tanto social como étnica, impidiendo, además, un desarrollo autónomo de los poderes internacionales. La consecuencia es que en el Perú no se puede hablar de una hegemonía de una clase dirigente.

14 Chirinos Soto, Enrique: Historia de la república: 1821-Perú-1978, Lima, 1977. 
meros atribuyen este alejamiento a la característica mercantilista del Estado peruano $;{ }^{15}$ los segundos a su carácter de clase y a su subordinación a los intereses económicos internacionales. En definitiva, el Estado en el Perú nunca ha sido representativo de la sociedad. Más aún, sólo lo ha caracterizado su fuerza coaccionadora, precisamente para sustituir esa incapacidad de representación. Pero hay que señalar que estos cuestionamientos, siendo ciertos, no son novedosos, pues ya están presentes en las reflexiones de pensadores tan importantes y distintos teórica e ideológicamente, como son Víctor Andrés Belaunde ${ }^{16}$ y Jorge Basadre. ${ }^{17}$

$\mathrm{Al}$ interior de la preocupación por entender el proceso formativo del Estado peruano, un punto polémico es determinar en qué momento se empieza a configurar como tal. Algunos autores señalan que ello empieza a ocurrir desde el gobierno de Nicolás de Piérola, luego de derrotar al general Andrés Avelino Cáceres en la guerra civil de 1894-1895. Otros sostienen que la consolidación del Estado peruano sólo empieza a producirse durante el oncenio de Augusto B. Leguía (1919-1930), algunos más afirman que ello ocurre en el tiempo del reformismo militar del general Juan Velasco Alvarado (1968-1975). Finalmente, hay quienes argumentan que la consolidación de un verdadero Estado nacional en el Perú se está produciendo durante el gobierno de Alberto Fujimori (desde 1990). Como se puede observar, se trata de un asunto aún sin resolver.

\section{Sobre el Estado peruano: propuesta de lectura}

En las ciencias sociales peruanas se suele estudiar la realidad contemporánea a partir de los años finales de la década del veinte, es decir, desde Augusto B. Leguía, José Carlos Mariátegui y Víctor Raúl Haya de la Torre. Lo inmediatamente anterior (principios de siglo) se considera parte de un "antiguo régimen" poco digno de atención. Evidentemente, se trata de una visión recortada, pues es necesario retroceder en la historia para ubicar en sus orígenes reales a muchos de los procesos que se consolidarán posteriormente y no entender a éstos sólo como un momento absolutamente radical y fundacional, sin historia.

15 De Soto, Hernando: El otro sendero, Lima, 1986.

16 Belaunde, Víctor Andrés: La crisis presente [1914]. Lima, 1994.

17 Basadre, Jorge: Perú: problema y posibilidad [1931]. Lima, 1978. 
El derrotero de conformación del Estado peruano no es lineal y sin sobresaltos; tampoco una sucesión de etapas. Por esta razón, para seguir su proceso es necesario plantearse algunas preguntas. Una de ellas está referida a la presión de determinados grupos sociales que buscan la ampliación del sistema político. En los años del orden oligárquico, por ejemplo, oponerse a éste significaba el reclamo por ampliar los linderos de la participación política. En otras palabras, se trataba de conquistar un derecho ciudadano que se restringía a unos pocos sectores privilegiados.

Otra pregunta es la que se refiere a la conquista de derechos. En un país como el Perú, donde las grietas culturales no han sido cerradas del todo, la ampliación ciudadana se ve seriamente obstaculizada, a pesar de los avances integradores efectuados desde mediados del presente siglo. Desde una lectura histórica, uno puede observar que la población indígena - mayoritaria en el Perú - usualmente ha quedado excluida de lo que el discurso estatal ha definido como la "nación" y, por tanto, de sus derechos ciudadanos..$^{18}$

Si bien construir el Estado monoétnico fue un proyecto común de las oligarquías latinoamericanas, sus consecuencias más graves se revelaron en países como el peruano, donde la población indígena era la predominante. ${ }^{19}$ Por lo tanto, la construcción de una sociedad y de un Estado "nacionales" implicaba la resolución de estos dos niveles: social, de clase; y cultural. ${ }^{20}$ Dicha situación empezó a variar - por presión de las clases subalternas y de sus representantes políticos- desde, aproximadamente, los años cincuenta del siglo XX.

Esta realidad compleja nos obliga a contrarrestar la visión lineal y organicista que ha predominado en los análisis sobre la evolución del Estado, no sólo del Perú, sino de los países latinoamericanos en general.

18 Para el análisis de procesos de ciudadanía que rompen con los marcos exclusivamente clasistas ver Turner, Bryan: "Outline of a theory of citizenship", en Chantal Mouffe: Dimensions of radical democracy, London, 1992.

19 Cuando se refiere a Estado monoétnico, Marcos Roitman utiliza la expresión en su sentido político más que antropológico, entendiéndolo "como integrador de clases sociales étnicamente homogéneas y cuyo ejercicio del poder queda reservado a sus miembros, independientemente del lugar que ocupen en la estructura social. Siendo sus valores, simbología y proyección cultural lo que determina su sentido de pertenencia política a lo nacional-estatal". Roitman, Marcos: Democracia y política en América Latina, Caracas, 1993, págs. 81-82.

20 Sobre las posibilidades y los límites que existen para construir un orden político democrático en los países andinos, y dentro de un panorama actual, se puede consultar Adrianzén, Alberto et al: Democracia, etnicidad y violencia política en los países andinos, Lima, 1993, y en concreto Degregori, Carlos Iván: "Identidad étnica, movimientos sociales y participación política en el Perú", en Ibidem, págs. 113-333. 
En resumen, entender el proceso de constitución del Estado peruano significa asumir el punto de vista de que se trata de un producto de cambios constantes en los que ciertas etapas tradicionalmente aceptadas (como oligarquía, populismo, reformismo militar, democracia) no se cancelan, sino que se imbrican e interpenetran. La peculiar manera como se relacionan los procesos sociales y su expresión en el terreno estatal permite acercarnos a una explicación global de las formas en que se construyen el Estado y la sociedad en el Perú.

\section{Periodización del Estado peruano en el siglo XX}

La periodización que sigue toma como objeto de análisis los cambios y las continuidades que caracterizaron al Estado peruano desde la república de notables hasta la actualidad. Los otros procesos y actores sociales o políticos (elites, partidos o movimientos sociales, por ejemplo) son tomados en cuenta en la medida que permitan iluminar el proceso constitutivo del Estado en el Perú. Tambien deseo mencionar que no me interesa seguir dicho camino con el tedio de describir cada gobierno, sino descubrir las tendencias generales que hallo en cada período.

La parcial institucionalización, característica de la república de notables (1894-1919), tenía su sostén en las alianzas familiares que adquirieron "notabilidad"21 por distintas razones ${ }^{22}$ y que guardaban diferencias tanto en sus orígenes sociales como en los regionales y económicos. En este período, el Estado estaba caracterizado por la captura del poder en manos de un pequeño grupo de familias, conocido como la oligarquía peruana. Aunque no existía una base ciudadana amplia (los movimientos de las clases subalternas por conquista de derechos eran esporádicos), la república de notables marcó el inicio de construcción de cierta institucionalidad estatal que, aunque precaria, trataba de establecer las bases de un poder central.

Al Estado de los notables hay que entenderlo como un pacto en el que distintas fracciones acordaron (no siempre de manera armoniosa y pacífica) viabilizar un sistema de dominio y una forma de organización social

21 Por eso, algunos autores prefieren llamar al sistema político de este período como república de notables (Franco, Carlos y Neira, Hugo: El problema de las élites y el pensamiento. Los novecentistas peruanos. 1895-1930, Sevilla, 1986). México, 1990

22 Balmori, Diana et al.: Las alianzas de familias y la formación del País en América Latina, 
que los beneficiara. De esta manera, agroexportadores (especialmente azucareros), financistas y poderes locales (o gamonales) establecieron un pacto en el que cada uno respetaba las instancias de los otros, y que excluía a las clases subalternas de mínimos derechos políticos y sociales. Si bien en este diseño de Estado los poderes locales tenían una gran influencia política y económica, se establecieron ciertas reglas que se hacían respetar, incluso a la fuerza..$^{23}$ No obstante, no puede decirse que el dominio oligárquico fuera monolítico y que impidió la aparición de fuerzas exógenas que golpeaban las murallas del sistema político para querer derruirlas.

Una expresión de esas fuerzas cuestionadoras fue la incipiente coalición populista que se formó en 1912, bajo el liderazgo del empresario salitrero, Guillermo E. Billinghurst, quien llegó a la presidencia del Perú (1912-1914) apoyado por un importante movimiento urbano-popular. Dicha coalición se debió a la acción de grupos sociales que aún no cuajaban como actores de clase claramente diferenciados respecto de las elites y del Estado, con conciencia y organización propias. Se trató, por el contrario, de una masa indiferenciada en términos de clase pero no necesariamente de una masa disponible, según la calificación que utiliza Gino Germani ${ }^{24}$ para otro caso nacional. No obstante su derrota (pues el billinghurismo sólo duró dieciséis meses) estos grupos urbano-populares abrieron el camino a procesos que se revelarán fundamentales en los años veinte, cuando las clases subalternas consigan niveles más altos de organización y autoconciencia política y se conviertan en los ejes del populismo paradigmático de la historia peruana, el del oncenio leguiísta.

Esta etapa tan importante de la historia peruana usualmente ha sido analizada desde la referencia de las clases populares. Ello ha impedido destacar los intentos institucionalizadores de ciertas elites de aquel entonces por considerarlas, en su conjunto, antinacionales y reaccionarias, descontextualizando sus prácticas y discursos. Estos años son, en definitiva, los de la fundación del Estado moderno peruano, no obstante los posteriores vaivenes de éste.

La centralización populista y la aparición de las clases subalternas durante el gobierno de Augusto B. Leguía (1919-1930) estuvieron caracte-

23 Este conflicto entre poderes locales y proyecto de constitución de un poder central se observa con nitidez en la disputa por el uso legítimo de la violencia. Ello explica el interés de Nicolás de Piérola (1895-1899) por profesionalizar a las fuerzas armadas y convertirlas en parte de un aparato estatal nacional.

24 Germani, Gino: Política y sociedad en una época de transición. Buenos Aires, 1968. 
rizadas por el protagonismo caudillista y por una nueva estructuración del Estado en la que los grupos financieros, conectados con los circuitos internacionales, adquirieron gran relevancia; mientras tanto, las clases subalternas mostraban altos niveles organizativos políticos e ideológicos.

Es cierto que Leguía arrebató el poder político a las elites oligárquicas, pero no las despojó de su poder económico. Si bien las oligarquías regionales perdieron el control político siguieron manteniendo - e, incluso, ampliaron - su base económica, gracias a la política leguiísta de atraer - de modo ya definitivo- al capital norteamericano, ${ }^{25}$ con el que establecieron alianzas.

En efecto, bajo el leguiísmo, el capital imperialista norteamericano controló las finanzas estatales y los sectores económicos claves como la minería, el petróleo, la producción azucarera y la industria. El oncenio de Leguía trató de desarrollar - y lo consiguió parcialmente- "una activa política centralista". ${ }^{26}$ Una muestra de esto fue la creación, en 1922, del Banco de Reserva del Perú. Sólo desde ese momento se puede hablar de una moneda nacional. ${ }^{27}$

Por otro lado, al interior del proyecto de centralización política, el leguiísmo tuvo presente la necesidad de definir los linderos geográficos del país para evitar nuevos conflictos bélicos inconvenientes. Durante el llamado oncenio se firmaron los tratados fronterizos con Ecuador, Chile y Colombia) que, si bien fueron cuestionados en su momento, ayudaron a definir el contorno físico del país. ${ }^{28}$

En su relación con las clases trabajadoras, Leguía buscó reglamentar los conflictos laborales adecuando al Estado para que cumpliera con el arbitraje obligatorio. Su gobierno también dictó una legislación para proteger a la clase media, sentando las bases de creación de una legislación "con principios jurídicos autónomos", aun cuando en el plano político tuviera repercusiones negativas para el movimiento trabajador por el fraccionamiento que ocasionó en éste. ${ }^{29}$

25 Leguía - señala Ernesto Yepes - si bien en lo fundamental no alteró la riqueza y privilegio de las clases dominantes, significó en cambio el desplazamiento definitivo de la fracción hegemónica civilista de las instancias más altas del poder político" (Yepes, Ernesto: Perú 1820-1920. Un siglo de desarrollo capitalista, Lima 1972, pág. 283).

26 Cotler, Julio: Clases, Estado y..., pág. 186.

27 Ibidem, págs. 185-186.

28 Sobre la importancia de la delimitación geográfica en la demarcación político-estatal ver Slater, David: Territory and State Power in Latin American: the Peruvian Case, London and New York, 1989.

29 Santistevan, Jorge y Ángel Delgado: La huelga en el Perú. Historia y derecho, Lima, 1980. 
El proceso modernizador que impulsó el leguiísmo trajo como consecuencia la aparición de nuevos sectores sociales, como las clases medias (básicamente burócratas, periodistas y estudiantes universitarios), y obreros (de la construcción especialmente, por las obras viales que se ejecutaron en esos años). Ambos, clases medias y trabajadores, confluyeron en amplios movimientos organizativos, primero para reivindicaciones sectoriales y luego con claros perfiles políticos. Por ello, no es casual que el gran partido de masas del Perú del presente siglo — el APRA, fundado por Haya - tuviera sus orígenes en los años del gobierno leguiísta. Igual ocurrió con la organización obrera bajo el signo marxista orientado por Mariátegui. Un estudiante universitario y un periodista se convirtieron en los principales conductores de los nuevos contingentes sociales surgidos en los años veinte, y que tendrían una profunda influencia en los años posteriores.

No obstante, la caida del oncenio no se produjo por la lucha de las masas, ni por las fuerzas políticas radicales de oposición, sino por la caida brusca de las exportaciones producidas entre los años 1929 y 1932, como consecuencia de la crisis internacional. Al quedarse el Estado sin recursos, se desbarató la política populista de Leguía, abriendo el camino para el retorno al poder de las familias oligárquicas.

Queda aún por desentrañar el papel y la importancia del populismo en la formación del Estado en el Perú (y seguramente en toda América Latina). ¿Existe una relación directa y causal entre populismo y formación estatal?, ¿es acaso el populismo el que explica la constitución del Estado?, ¿se trata de una movilización exclusivamente "desde arriba"? En cualquier caso, por incorporar a las masas no sólo a la política sino también a la vida social, al populismo puede vérsele como el creador de un nuevo espacio de relaciones dentro del cual, paulatinamente, se forma entre las clases subalternas cierta conciencia de pertenecer a un determinado ámbito estatal. ${ }^{30}$

El período de la recomposición oligárquica y la recuperación de los poderes privados (1930-1968) expresó la vuelta de las familias oligárquicas, aunque éstas ya no tenían las mismas características del período 18951919. Social y culturalmente ya no las identificaban los valores de honorabilidad, decencia y respeto por ciertas formas; esto se tradujo en el ámbito político en su apelación a las dictaduras con el objeto de controlar el poder político. Los viejos partidos (como el Civil, el Demócrata, el Constitucio-

30 Franco, Carlos y Hugo Neira: El problema de las élites.... Adrianzén, Alberto: "Estado y sociedad: señores, masas y ciudadanos", en Juan Abugattas et al.: Estado y sociedad: relaciones peligrosas. Lima, 1990. 
nal y el Liberal) habían desaparecido y el parcial proyecto institucionalizador del Estado fracasado, en gran parte por la irrupción en la vida política y social de las clases populares que — por reacción— hizo cerrarse más a las elites oligárquicas. Además, éstas contaban con el auspicio activo de los militares, quienes se constituyeron desde entonces en los celosos defensores de sus intereses (alianza que se conoce como el civil-militarismo).

En efecto, la situación del Perú de fines de los veinte e inicios de los treinta era caótica. Frente a la crisis ocurrida desde los últimos meses del leguiísmo, nuevamente la vieja oligarquía —especialmente los terratenientes del sur- encontró la oportunidad para retomar el poder mediante el golpe militar de agosto de 1930 comandado por el coronel Miguel de Sánchez Cerro. Como en 1914 — cuando la oligarquía despojó del poder a Billinghurst-, ésta acudió a los cuarteles para liquidar un gobierno incómodo y recuperar el control político. Evidentemente, se nota en esta nueva etapa una revitalización de los poderes privados que echaron abajo ciertas medidas de constitución de un poder central que venían siendo adoptadas desde la república de los notables.

Con respecto a las clases populares, hay que mencionar que éstas no habían permanecido pasivas como cuando ocurrió el golpe de 1914 contra Billinghurst ${ }^{31}$ por el contrario, la situación de crisis — pre-revolucionaria para algunos-, las impulsó a desarrollar una participación política más activa, además porque esta vez sí había conductores ideológico-políticos, especialmente Haya de la Torre. Mariátegui no pudo ver esta convulsionada etapa de la historia republicana peruana por su muerte, ocurrida en abril de 1930.

Haya, quien había sido desterrado por Leguía en $1923,{ }^{32}$ pudo volver al Perú - luego del derrumbe del oncenio - para participar en las elecciones presidenciales de 1932. Para entonces ya había fundado la Alianza Popular Revolucionaria Americana (APRA) como partido en 1930, con un proyecto de construir un Estado que integrara a los sectores mayoritarios excluidos. Haya, que no era un desconocido para la clase trabajadora peruana, y limeña en especial, se reencontró con los sectores trabajadores de Lima y les recordó sus jornadas de 1919 por las ocho horas y la alianza obrero-estudiantil en mayo de 1923 contra el oncenio. La respuesta que

31 Rosel, María Cristina y Ernesto Yepes: "La caida de Billinghurst: crónica diplomática de un golpe de Estado", en Análisis, núm. 12, Primer semestre, 1983.

32 El motivo fue que Haya encabezó la oposición al intento del leguiísmo de aliarse - mediante la consagración del Perú al Sagrado Corazón— con las tradicionales jerarquías de la Iglesia Católica. 
recogió fue multitudinaria e hizo que la oligarquía viera amenazado nuevamente su poder. Los niveles de politización de las clases subalternas - especialmente de los trabajadores urbanos y más organizados- se mostraban en toda su dimensión. El triunfo electoral de la oligarquía corría peligro.

Ante la formación de las clases marginadas como sujeto político, las familias oligárquicas recurrieron nuevamente a Sánchez Cerro para las elecciones generales. Él era el único que podía derrotar a la fuerza masiva que el aprismo había comenzado a forjar, pues su origen mestizo-popular entronizaba con el de la mayoría integrante del pueblo. Por ello, una vez conocido el resultado, el triunfo correspondió a Sánchez Cerro. El aprismo reclamó por lo que consideraba era un robo de su victoria electoral. La protesta devino guerra civil con el aplastamiento de los rebeldes apristas por parte del ejército en 1932. En ese mismo año asesinaron a Sánchez Cerro y ante la nueva crisis volvió el para ese entonces ya general Óscar R. Benavides, el mismo militar que destituyó a Billinghurst. La oligarquía recuperó el control del poder, pero desde entonces ya no podrá separarse de su brazo armado.

Advino una etapa oscurantista en la historia peruana, de dominio casi absoluto de las familias oligárquicas, de escaso brillo cultural y de marginación de las clases subalternas mediante la represión y la persecución política (especialmente de apristas). El Estado fue recapturado por los poderes privados más reaccionarios, y los intentos por construir un poder central se vieron aplazados.

La situación cambió temporalmente con el fin de la Segunda Guerra Mundial en 1945 y con la derrota del fascismo y del nazismo. El aprismo recuperó la legalidad y se abrieron ciertos espacios para la participación de las clases subalternas en un proceso electoral. El APRA auspició el Frente Democrático Nacional (FDN), el que ganó ampliamente las elecciones de 1945. Pero esta experiencia democrática sólo duró tres años, pues la crisis económica y los conflictos al interior del Frente, echaron por tierra los intentos de formar un gobierno sólido. ${ }^{33}$

Luego del fracaso del FDN, las elites oligárquicas reaparecieron con un rostro peculiar en el populismo autoritario y conservador del general Manuel A. Odría (1948-1956). Si bien durante su gobierno el Estado se retrajo de intervenir en la economía, tuvo importantes ingresos como pro-

33 Portocarrero, Gonzalo: De Bustamante a Odría. El fracaso del Frente Democrático Nacional, 1945-1950. Lima, 1983. 
ducto del auge de la exportación de minerales. Estos ingresos permitieron a Odría acercarse a las clases medias y a los sectores populares por medio del ofrecimiento de ciertos servicios (hospitales, escuelas, espacios de recreación), además de la ampliación del derecho al voto a las mujeres alfabetas, con lo que expandió el contingente electoral en el país. Ello explica que hasta hace una generación aproximadamente, el ochenio odriísta fuera el más recordado en la mentalidad popular.

Por su parte, la sociedad también había cambiado. Durante los años del ochenio es cuando se empieza a generar uno de los hechos más trascendentales de la historia peruana contemporánea: las migraciones del campo a la ciudad, cambiando - andinizando — radicalmente el rostro del Perú, volviendo evidente su componente indígena-mestizo. ${ }^{34}$ De otro lado, en estos años el sector industrial iba creciendo también en importancia económica, lo que le permitió reclamar un lugar en el manejo del poder, cuestionando directamente la vigencia del pacto oligárquico que fundó la república de notables (entre agroexportadores, poderes locales y financistas).

Sin embargo, las luchas más importantes las protagonizaron los contingentes campesinos, quienes eran despojados de sus tierras tanto por las empresas mineras norteamericanas como por los terratenientes peruanos. En consecuencia, si bien el Estado pasó a ser recapturado por ciertas elites oligárquicas, la sociedad no permaneció pasiva y, por el contrario, exigió el reconocimiento de ciertos derechos. Una expresión nítida de las modificaciones de la sociedad peruana en esta época, fue la aparición de partidos representativos de los sectores medios, especialmente de Acción Popular (AP), liderado por Fernando Belaunde Terry, quien llegó a ser presidente del Perú por primera vez durante los años de 1963-1968, apoyado precisamente por aquellos contingentes a quienes se les había reconocido estatuto legal en el plano electoral.

En resumen, fueron treinta y ocho años en los cuales la política se desarrolló entre el autoritarismo militar, el dominio plutocrático y los populismos tanto civil (como el del Frente Democrático Nacional y el de Acción Popular) como militar (del general Manuel A. Odría). La característica común del Estado en estos años es que no pudo constituir una autoridad central, pero justamente esta precariedad institucional ocasionó una serie

34 Sobre la importancia de las migraciones ver Matos Mar, José: Desborde popular y crisis del Estado, Lima, 1985. Degregori, Carlos Iván, Blondet, Cecilia y Lynch, Nicolás: Conquistadores de un Nuevo Mundo. De invasores a ciudadanos en San Martín de Porres, Lima, 1986 y Franco, Carlos: La otra modernidad. Imágenes de la sociedad peruana, Lima, 1991, entre otros. 
de grietas en el dominio oligárquico que hicieron temer una revolución "desde abajo". ${ }^{35}$ En esas circunstancias apareció el reformismo militar del general Juan Velasco Alvarado.

El reformismo militar (1968-1975) significó la liquidación del sistema oligárquico, la constitución — como nunca antes- de un poder central en el Perú y la neutralización — temporal— de la precariedad política por medio de la anulación de los partidos políticos que en el período anterior - por sus disputas sin solución - obstaculizaron una serie de reformas que AP quiso llevar a efecto en los primeros meses de su gestión. Esta experiencia explica, en gran parte, el discurso del no-partido que caracterizó al velasquismo.

El reformismo militar estuvo dirigido por una cúpula militar y asesores civiles de distintas tendencias, pero todas antioligárquicas (como ex apristas, ex comunistas, ex guevaristas, demócratacristianos y socialprogresistas), que trataron de constituir un Estado nacional. En estos años se consiguió cierta estabilidad pero en autoritarismo, al interior de una economía que crecía y de una prédica nacionalista e integradora inédita hasta ese entonces en el Perú. Paradójicamente, a pesar de su formato autoritario que impedía ejercer los derechos políticos, el reformismo militar estimuló el auge organizativo de las clases populares que iban modificando sus patrones de relación con el Estado. ${ }^{36}$ En efecto, la explosión de gremios, sindicatos y centrales de trabajadores obreros y campesinos ${ }^{37}$ no registra en la historia peruana una intensidad similar para exigir y defender los derechos de las clases marginadas. ${ }^{38} \mathrm{Se}$ amplió un espacio ciudadano que anteriormente estaba reservado sólo para ciertos grupos privilegiados.

Bajo el velasquismo el Estado peruano amplió su influencia como nunca antes a gran parte del territorio nacional. Se crearon ministerios e instituciones estatales que trataron de acercarse a la sociedad. Por primera vez en la historia peruana se podía hablar de un proyecto real para conformar un Estado nacional. Sin embargo, un importante sector de trabajadores

35 Especialmente cuando sectores radicalizados de las clases medias protagonizaron las guerrillas — rápidamente derrotadas - en 1965, y que fueron dirigidas por un sector desgajado del APRA, que posteriormente se denominó Movimiento de Izquierda Revolucionaria (MIR).

36 Lynch, Nicolás: La transición conservadora. Movimiento social y democracia en el Perú: 1975-1978. Lima, 1992.

37 Como la revitalización de la central fundada por Mariátegui en los años veinte, la Central General de Trabajadores del Perú (CGTP) y la fundación de la Confederación Campesina del Perú (CCP).

38 Gonzales, Osmar: "Conquista ciudadana y democracia. Auge y crisis del clasismo en Perú (1968-1990)", en Revista Latinoamericana de Estudios del Trabajo, Año 2, núm. 4, 1996. 
— los más organizados - no aprovecharon estos nuevos espacios que ofrecía el reformismo militar para ampliar su participación ciudadana sino que, por el contrario, al lado de una izquierda marxista compuesta por diferentes partidos, se enfrascaron en una lucha frontal contra aquél - caracterizado desde pro-burgués hasta fascista - buscando radicalizar el proyecto reformista, siendo ésta una de las causas — no la única— del fracaso del reformismo velasquista.

Por otro lado, el Estado promovió explícitamente la industrialización del país. Nunca como entonces el sector industrial creció en importancia. Pero no todos los empresarios apoyaron este proyecto de desarrollo por razones básicamente ideológicas, aun cuando económicamente les favorecía la nueva política económica. Reclamaban al régimen las libertades políticas y el regreso al Estado de derecho, aduciendo que la excesiva intromisión del Estado en la vida económica — protegiendo a la industriaobstaculizaba la conformación de una burguesía sólida y competitiva. Estos grupos de industriales descontentos formaron, posteriormente, con ciertos partidos ${ }^{39}$ la oposición de derecha. Curiosamente, fueron ellos mismos - cuando el Perú regresó a la constitucionalidad en los años ochenta y el Estado se retraía de la economía- los que pidieron mayor protección estatal a la industria nacional ante la competencia "desleal" de los productos foráneos. En resumen, la frágil burguesía peruana —al igual que los trabajadores radicalizados - no supo aprovechar los beneficios de una política estatal que los favorecía plenamente.

Pero existe un elemento que permite calibrar mejor el esfuerzo velasquista por fundir Estado y sociedad y es el aspecto socio-cultural. En estos años, el Estado legitimó al quechua como la otra lengua oficial; reivindicó ciertos elementos del pasado indígena (como la figura de Túpac Amaru); se llenó de una simbología que recogía esa parte de la historia que en el discurso pre-velasquista sólo eran tomados como parte del folklore; además que otorgó cierta dignidad a los sectores excluidos a quienes hizo sentir parte de una colectividad nacional. En resumen, como señala Carlos Franco, ${ }^{40}$ el reformismo militar acercó a los distintos contingentes culturales mediante un discurso integrador que no por eso dejaba de ser vertical.

39 Como el Partido Popular Cristiano (PPC), fundado en los años sesenta como una escisión conservadora de la Democracia Cristiana (DC).

40 Franco, Carlos: "El sentido del velasquismo en la construcción de una comunidad nacional ciudadana en el Perú”, en Socialismo y Participación, núm. 63, Lima, 1993. 
En este contexto se produjo una tensión. Por un lado, el reclamo por un manejo privatizado del Estado y del poder político por parte de los sectores de derecha y, por otro, hacer del Estado una instancia nacional, en el sentido de que represente a la mayoría popular pero desde una postura maximalista y confrontacionista. Sumados a esta tensión hay que mencionar los conflictos producidos en el interior de la cúpula militar desatados luego de la enfermedad de Velasco, líder indiscutible del proceso. Finalmente, tras la muerte de éste vino la sucesión, que llegó por el ala más conservadora.

El período de la segunda fase del gobierno militar (1975-1990) y el retorno a la constitucionalidad en los años ochenta, si bien desde la historia política abarca gobiernos disímiles, desde el problema que interesa en este artículo - el proceso constitutivo del Estado- constituye un solo momento, caracterizado por la crisis del Estado en su capacidad por mantener una autoridad nacional luego de la experiencia velasquista.

En efecto, durante el gobierno de Francisco Morales Bermúdez el Estado inicia una etapa de privatización en el manejo del poder. La "segunda fase" se caracteriza por la regresión de las reformas velasquistas para otorgar privilegios a ciertos grupos de poder económico, especialmente los exportadores. Esto se dio en un contexto económico muy distinto al que viviera el reformismo militar, pues es el tiempo en que la crisis económica empezaba a mostrar sus primeros efectos. Ante ello, el gobierno aplicó las primeras medidas de ajuste: baja de salarios, despidos masivos, alza del costo de vida. A ellas acompañó un paulatino pero consistente retroceso del Estado en cuanto a su intervención en la economía. Al mismo tiempo, el gobierno desató una fuerte represión contra los dirigentes de los sectores trabajadores, haciendo retroceder los derechos que éstos habían conquistado durante el velasquismo. No obstante, la oleada de amplias protestas sociales fue sumamente poderosa arrinconando al gobierno y forzándolo a cumplir con la promesa de la vuelta a un régimen constitucional, la cual se produce por medio de dos etapas: convocatoria a una Asamblea Constituyente en 1979, y elecciones generales en $1980 .^{41}$

El nuevo triunfo de Acción Popular (1980-1985) inaugura la vuelta a la democracia. Ésta despertó grandes expectativas en cuanto a que se podían resolver los principales problemas económicos que el anterior gobierno militar había dejado como herencia. Con respecto al Estado, se pensó que

41 Nieto, Jorge: Izquierda y democracia en el Perú, Lima, 1983. 
éste podía generar las condiciones para volverse más nacional, porque iba a ser representativo de todas las fuerzas sociales. Pero la democracia estuvo acompañada de dos enemigos mortales: la crisis económica que se iba profundizando, y la violencia subversiva, protagonizada especialmente por Sendero Luminoso. A ninguno de estos dos graves problemas supo dar AP soluciones que generaran una identificación de la sociedad con el Estado, por el contrario, su incapacidad hizo que se separaran aún más. En lo económico, el gobierno acciopopulista efectuó reformas liberales tibias, por temor a perder la escasa base social que había acumulado (básicamente sectores medios en decadencia y alta burguesía). En materia antisubversiva, cierta lentitud y falta de reflejos le impidieron enfrentar la guerra de manera eficaz. La incapacidad para gobernar a una sociedad convulsionada como la peruana hizo que el único mérito de AP fuera terminar su mandato y entregarlo a otro partido legítimamente elegido.

El gobierno del APRA (1985-1990) continuó con la tendencia de distanciamiento entre el Estado y la sociedad que ya se observaba desde la "segunda fase". A pesar de un discurso populista en el que integraba como masa a los contingentes populares, y del carisma del líder, Alan García, el gobierno aprista no pudo ni quiso hacer nada contra la tendencia privatizadora del poder. En cuanto a la economía, en un primer momento el gobierno aprista trató de atraer a los empresarios nacionales para que invirtieran en el propio país, pero los grupos de poder económico prefirieron sacar sus capitales hacia mercados que consideraban más seguros. Esta medida dejó sin recursos al Estado. Ante una situación de crisis económica que se prolongaba sin visos de solución, el gobierno aprista sólo intervino en funciones de asistencia social, pero no diseñó un nuevo modelo de acumulación. Por otra parte, tampoco fue capaz de detener la espiral subversiva que crecía incontrolablemente; incluso se llegó a temer un nuevo golpe de Estado.

Con respecto a las clases populares, el gobierno aprista llevó a cabo una gestión de tipo populista en la que un sector de las clases populares (el de los desorganizados o informales) sirvió como cliente. Éstas, por su parte, luego de experimentar un gran auge organizativo y de movilización en los años setenta, con la crisis se desarticularon y perdieron su capacidad de influir en las decisiones estatales. ${ }^{42}$ Ante la manifiesta incapacidad del

42 A pesar de que, desde 1980, contaban con una importante fuerza electoral representada por Izquierda Unida. 
gobierno aprista en todo nivel y la profundidad de la crisis de representación de los partidos políticos existentes, aparecieron en el escenario político los llamados independientes o outsiders, quienes controlan al Estado peruano desde 1990.

En resumen, en estos años el Estado transitó por un proceso en el que se va desatendiendo paulatinamente de sus funciones reguladoras, proceso que culmina con el gobierno de Alberto Fujimori, el mismo que empieza una nueva etapa en la vida del Estado peruano.

La reestructuración liberal (desde 1990 hasta la actualidad), se produce en un momento de desarticulación casi total de la sociedad peruana. Por un lado, una economía que no superaba la crisis y que, incluso, se hundía en ella, agudizando la pobreza y sus consecuencias (delincuencia, marginalidad, corrupción). Por otro, en lo social se manifestaba un exacerbado individualismo y una gran incapacidad de establecer lazos sociales duraderos; la sociedad peruana se convirtió en el escenario óptimo para "el sálvese quien pueda", situación extrema que algunos autores caracterizaron como anómica; ${ }^{43}$ y que en casi todos los noventa se distinguió por su apatía y desmovilización. En lo político, la crisis de representación de los partidos llegó a sus extremos en este período, lo que la sociedad ha sancionado reiteradamente en todas las elecciones que se han producido durante la presente década. Sólo en el plano de la guerra contra la subversión la sociedad peruana ha vivido cierto alivio, pues el gobierno fujimorista ha logrado, si no desmantelar, minimizar los efectos perversamente corrosivos que ella había estado ocasionando desde 1980.

La situación descrita exacerbó la centralización caudillista arropada por una casta tecno-militar, en la cual los fueros de los poderes estatales se fundieron de manera única en los deseos del presidente y su entorno. El excesivo protagonismo caudillista ha tenido una consecuencia funesta en el plano estatal: centralización del poder en beneficio de los poderes privados. De esta manera, y forzando la imagen, el Estado peruano retornó al punto de donde partió en los inicios del siglo XX: la concentración del poder político en una elite, pretendiéndose explícitamente que la política no forme parte de las preocupaciones ciudadanas. Como nunca, el Estado peruano en los noventa se encontró distanciado de la sociedad.

43 Neira, Hugo: "Violencia y anomia. Reflexiones para intentar comprender", en Socialismo y Participación, núm. 37, Lima, 1987. Lynch, Nicolás: "Anomia de regresión o anomia de desarrollo", en Ibidem, núm. 46, Lima, 1989. 


\section{Colofón}

Luego del recorrido — rápido y apretado - por el camino seguido por el Estado peruano en el siglo XX, se pueden apuntar algunas consideraciones finales.

En primer lugar, espero haber mostrado una relectura sobre el proceso del Estado peruano en el que las diferentes etapas que lo constituyen no forman una sucesión lineal, sino que pueden existir retrocesos y en que cada etapa le puede deber a la anterior algo (mucho o poco) de su carácter. Así, partiendo desde el tiempo de los notables, pasando por el populismo de Leguía, la recomposición oligárquica, el reformismo militar, el retraimiento del Estado y terminando en la reestructuración liberal, hemos podido observar las tensiones que han permanecido en todo el siglo entre Estado y sociedad, y entre poderes privados e intentos de centralización del poder que significa, al final de cuentas, cierto proyecto por constituir al Estado peruano como un actor racional.

En una mirada de largo plazo, también podemos observar — desde principios de siglo hasta el momento presente- una derrota de los sectores sociales marginados por ampliar los espacios de influencia en las decisiones estatales, más allá de ciertas conquistas producidas en diferentes momentos históricos en las que pudieron ejercer presión con éxito para ser incluidas en el ámbito estatal. Si bien en el terreno jurídico esas conquistas se han visto refrendadas, no han generado impactos decisivos ni en las prácticas políticas ni en el Estado. Por el contrario, las políticas estatales se concibieron y se convirtieron en decisiones en el interior de una caja negra a la cual la sociedad no tenía acceso. No obstante, esas victorias parciales han tenido su efecto en las formas como el Estado se ha relacionado con la sociedad en diferentes momentos históricos, especialmente en aquéllos cuando la sociedad ha expresado capacidad de movilización y de reclamo.

La tensión entre el proyecto de constitución de un poder central y el de preservar el control del Estado para ciertos sectores privilegiados se ha resuelto hasta el momento en favor de los segundos, en gran medida porque los espacios de ampliación ciudadana que se fueron conquistando por oleadas sucesivas se redujeron notablemente hacia finales del siglo XX. De esta manera, el Estado peruano no ha podido constituirse como una instancia nacional de resolución de conflictos por encima de los diferentes intereses fragmentados que componen la sociedad peruana. Por ello, podemos concluir que el Estado peruano no se ha convertido en un actor racional, 
según lo ha definido Mann: ${ }^{44}$ como una arena de resolución de conflictos, con un poder autónomo de los diferentes intereses sociales en el interior de un territorio demarcado políticamente. Por el contrario, los intereses privados han prevalecido y un sentido "nacional" de gobernar brilla por su ausencia, sin que encuentren ninguna oposición efectiva por parte de los diferentes grupos sociales, al menos hasta el momento. Un "despertar" de la sociedad civil abriría un nuevo capítulo en la historia política peruana, y eso es lo que se espera en el actual momento post-fujimorista. 